
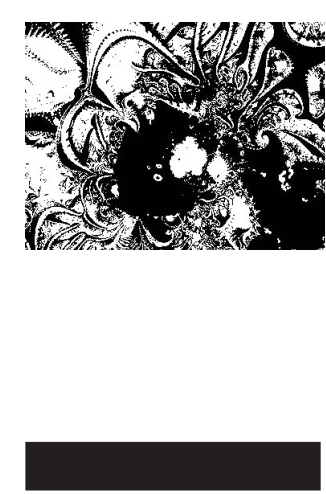

Acknowledgment This paper grew out of a plenary talk that the senior author gave at the 21 st Annual Conference of Croatian Psychologists held on 6 to 9 November 2013 in Zagreb, Croatia.

\title{
THE PERCEIVED QUALITY OF WORKING LIFE IN CROATIA AND THE EUROPEAN UNION
}

Branimir ŠVERKO, Zvonimir GALIĆ

Faculty of Humanities and Social Sciences, Zagreb

UDK: $331.101 .3(497.5: 4-6 E U)$

Izvorni znanstveni rad

Primlieno: 25. 2. 2014.

This study explores the perceived quality of working life (QWL) in Croatia and in two groups of EU countries: the EU17, which comprises established market economies of Western Europe, and the EU10, which consists of ten Central and Eastern European (CEE) countries. The analysis draws upon the database of the Fifth European Working Conditions Survey, the fieldwork for which was carried out in 2010. The number of participants was 24,424 in the EU17, 10,948 in the EU10, and 1,100 in the Croatian sample. Four dimensions have been constructed to measure the QWL: (1) economic security, (2) social relations at work, (3) meaningfulness of work, and (4) autonomy and participation in making decisions. The results show that the CEE countries lag behind the Western European countries, in particular in economic security. In a hierarchical cluster analysis the two groups are bundled together in separate clusters, indicating that a pronounced East-West divide in quality of working life continues to exist. Croatia, although with relatively high ratings on social relations, clusters together with the other transitional countries.

Keywords: quality of working life, job quality, cross-national comparison, the European Union, Croatia

$\triangle \quad$ Zvonimir Galić, Department of Psychology, Faculty of Humanities and Social Sciences, University of Zagreb, I. Lučića 3, 10000 Zagreb, Croatia.

E-mail: zgalic@ffzg.hr

\section{INTRODUCTION}

Recently, there has been a renewed interest in the quality of working life (QWL) or its overlapping construct of job quality (e.g., Findlay, Kalleberg, \& Warhurst, 2013; Gallie, 2013). This may be partly due to its paradoxical relationships with the eco- 
DRUŠ. ISTRAŽ. ZAGREB GOD. 23 (2014), BR. 4, STR. 557-575

ŠVERKO, B., GALIĆ, Z.: THE PERCEIVED.. nomic crisis. On the one hand, the crisis is threatening the quality of working life, because the attention has shifted to cost reduction and sustainable employment levels. On the other hand, a survival strategy in competitive business may require a motivated labor force enjoying a satisfactory quality of working life. Accordingly, one of the most pressing challenges has been to survive the crisis without degrading the quality of working life.

Improving employees' quality of working life is an important goal per se, because it contributes to the workers' well-being, but it also pays off in improved work motivation. There is a general conviction that QWL enhances the workers' motivation and, in turn, has a positive impact on the economic performance of firms. Although a correlational support for this conviction is ample, until recently the causal evidence was deficient. Recently, however, strong causal evidence came from a methodologically advanced study, which used a massive longitudinal database with 2,178 business units (Harter, Schmidt, Asplund, Killhamm, \& Agrawal, 2010). The study confirmed the causal impact of employee work quality perceptions on important bottom-line measures comprising customer loyalty, employee retention and financial performance of firms. We highlight this study because the statements used to assess the employees' work perceptions were similar, both in content and format, to the statements that we have used to assess the QWL in the present study.

\section{Conceptual framework}

The term "the quality of working life" (QWL) was introduced in the late 1960s with the intention "to emphasize the human dimension so often forgotten among the technical and economic factors in job design" (Davis, 1977, p. 53). A two-volume book, which was the result of an international conference, provided the first conceptualizations of the construct (Davis \& Cherns, 1975). However, as Lawler (1975) noted, no clear and widely accepted definition of QWL was formulated at that time. Thirty years later, after reviewing a range of definitions and theoretical elaborations that followed, Martel and Dupuis (2006) concluded the same - no universally accepted definition of QWL had been formulated yet. Thus, quality of working life can be described only as an umbrella term that encompasses many aspects of the work environment, which are deemed beneficial for the individual. These may include, for example, the level and equity of compensation, work intensity, physical working conditions, the quality of relationships among employees, prospects for career development, variety in the daily work routine, the levels of recognition and 
DRUŠ. ISTRAŽ. ZAGREB GOD. 23 (2014), BR. 4 STR. 557-575

ŠVERKO, B., GALIĆ, Z. THE PERCEIVED... appreciation at work, autonomy and participation in making decisions. Which of the factors will be encompassed depends largely on the author's purpose and theoretical perspective.

The present study adopts a psychological perspective. The quality of working life is seen as a subjective construct, reflecting the individual's experiences and, by implication, their needs. Drawing on a number of sources (e.g., Efraty \& Sirgy, 1990; Elizur \& Shye, 1990; Lawler, 1982; Sirgy, Efraty, Siegel, \& Lee, 2001) we conceive QWL in the terms of human needs satisfaction. Needs are internal states of an organism caused by a lack of something important for its survival or well-being. People share some basic needs and seek to satisfy them everywhere, including their workplace. The work environment, work experiences and work rewards are important sources of employees' need satisfaction. The degree of this satisfaction determines the quality of working life: the more the employees' needs are met, the higher the quality of their working life. Thus, we can define QWL as the perceived extent to which employees can satisfy their important personal needs through their activities in the workplace and experiences in the organization.

This definition implies that in identifying the core dimension of QWL we should begin with the analysis of human needs. Several theories of motivation have proposed taxonomies of human needs, including Maslow's (1954) Hierarchy of Needs Theory, Alderfer's (1972) ERG Theory, McClelland's (1985) Acquired Needs Theory, and Deci and Ryan's $(1985,2000)$ Self-Determination Theory.

After careful consideration of the needs theories, we identified four major dimensions of working life quality that correspond to the principal categories of human needs. Our QWL dimensions include (a) economic security, (b) social relationship at work, (c) work meaningfulness, and (d) autonomy in work and participation in making decisions.

The first dimension, economic security, refers to the condition of having a stable income that allows for the maintenance of one's standard of living. It also includes the probability that an individual will keep his or her job, or find a new one if needed. These conditions are essential for satisfying the "basic" human needs, which represent the fundamental layers in the hierarchy of the needs theories. In Maslow's (1954) five-layer needs hierarchy, at the bottom are physiological needs and safety needs, supposed to be met before progressing on to higher level needs. Alderfer (1972) integrated Maslow's physiological and safety needs in one category that he labeled as the "existence needs". For these needs, economic security is the principal "satisfier". 
DRUŠ. ISTRAŽ. ZAGREB GOD. 23 (2014), BR. 4, STR. 557-575

ŠVERKO, B., GALIĆ, Z.: THE PERCEIVED...
The second dimension concerns the amount and quality of social relations at work. Their importance has been widely recognized: all of the needs theories postulate the category of social needs that has been variously termed as "love and belongingness needs" (Maslow, 1954), "relatedness needs" (Alderfer, 1972; Deci \& Ryan, 1985, 2000), or "affiliation needs" (McClelland, 1985). These needs include the desire to interact, to be connected to a group, and to experience caring for and by others. In spite of some differences in the conceptualization of these needs (i.e., whether they are universal and innate, or acquired through socialization), all theories agree that their satisfaction is necessary for human well-being.

The third dimension refers to meaningful work in which workers are able to make a worthwhile contribution to the valued outcomes. A meaningful job is one that allows creative work activity, and renders the feelings of usefulness and achievement. All major theories of motivation emphasize the importance of such feelings. In the needs-based theories, they are essential for satisfaction of the higher-order needs (Maslow's "esteem needs" and "self-actualization" or Alderfer's "growth needs"). Herzberg's theory of job satisfaction and motivation (1966; Herzberg, Mausner, \& Snyderman, 1959) stresses the importance of "motivators" which include the intrinsic sources of satisfaction, such as achievement, recognition, the work itself, and responsibility. Finally, in the Job Characteristics Theory (Hackman \& Oldham, 1976) the "experienced meaningfulness of work" is a major mediating construct used to explain how the core job characteristics (i.e. skill variety, task identity, and task significance) impact job motivation, satisfaction, and performance.

The fourth dimension concerns autonomy in work and participation in making decisions. The idea that workers should play a more active role in making decisions which impact their working conditions has been a central tenet of a voluminous literature on "industrial democracy". It was also a distinctive characteristic of early QWL programs in industry (e.g., Guest, 1979; Kornbluh, 1984). In psychological theories, autonomy is especially stressed in the Self-Determination Theory (Deci \& Ryan, 1985, 2000). It considers autonomy as the universal urge of humans to be causal agents in their lives; when satisfied, it yields enhanced intrinsic motivation and higher well-being. In the Job Characteristics Theory (Hackman \& Oldham, 1976), a degree of autonomy allowed to employees in scheduling their work and determining how it is to be done is viewed as one of the core dimensions that affect job satisfaction and performance.

Thus, there is substantial theoretical support for conceptualizing the QWL in terms of the four dimensions. Other 
DRUŠ. ISTRAŽ. ZAGREB GOD. 23 (2014), BR. 4 STR. 557-575

ŠVERKO, B., GALIĆ, Z. THE PERCEIVED... authors, however, have proposed more exhaustive taxonomies. The well-known Vitamin Model (Warr, 1999, 2007) comprises twelve principal job characteristics that affect well-being. Yet the two taxonomies are not incompatible. The four dimensions proposed here are simply wider and, as such, can subsume most of Warr's principal job characteristics. For example, Warr's attributes "availability of money", "career outlook", and "equity" are all comprised in our dimension of economic security, while "contact with others", "supportive supervision", and "valued social position" are components of social relations at work.

Since the quality of working life is a multidimensional construct, which encompasses a number of often unrelated attributes, constructing a single overall QWL indicator would not be suitable. QWL is better gauged with a system of a few major dimensions, which are relatively unrelated but each encompasses a certain number of interrelated components. The four dimensions proposed here are conceived as the elements of such a system. Their operationalization follows in the methodological section.

\section{Research objectives}

As the EU expands its borders, "the differing norms in terms of both working and living conditions across the continent become increasingly apparent. For Europe's policymakers, such differences present serious challenges as they seek to increase productivity, boost employment and improve quality of work. In this context, understanding the conditions of work across the different EU Member States and other European countries is of fundamental importance." (Eurofound, 2007; Foreword).

Croatia's recent accession to the $\mathrm{EU}^{1}$ was the initial impetus for the present study. The initial objective was to explore the perceived quality of work life in Croatia in comparison with two groups of the EU member states. The first group (EU17) comprised 17 established market economies of Western Europe, including the two Mediterranean island countries (Austria, Belgium, Cyprus, Denmark, Finland, France, Greece, Germany, Ireland, Italy, Luxemburg, Malta, the Netherlands, Portugal, Spain, Sweden, and the UK). The second group (EU10) consisted of the ten transitional countries of Central and Eastern Europe (CEE), former socialist countries, which joined the EU in the last ten years (Bulgaria, the Czech Republic, Estonia, Hungary, Latvia, Lithuania, Poland, Romania, Slovakia, and Slovenia). Since Croatia belongs to the CEE group and strives toward the EU-17 development level, the two groups of countries make relevant benchmarks. 
DRUŠ. ISTRAŽ. ZAGREB GOD. 23 (2014), BR. 4, STR. 557-575

ŠVERKO, B., GALIĆ, Z. THE PERCEIVED..

\section{METHODOLOGY}

Data source
Furthermore, in order to be used as a standard for the comparison, the two groups need to be compared with each other. Their mutual comparison is an important and timely issue. Almost a quarter of a century has elapsed since the CEE societies began their transition from a party-controlled planned economy toward a capitalistic democracy and a market economy. It is now time to evaluate whether and how the transition affected their development - not only in terms of economic performance, but also in terms of quality of life indicators such as the QWL dimensions. Hence, our second research objective was to examine how the quality of working life in the CEE countries compares to the levels in the advanced EU countries.

However, neither of the two groups of countries is likely to be homogeneous. There are marked differences in institutional regimes of various countries that are relevant for work-related issues (Esping-Andersen, 1990, 1999). Due to these differences, which are likely to impact the quality of working life (e.g., Gallie, 2007a, 2007b, 2009; Holman, 2013), the countries will probably tend to form several QWL based clusters. Hence, our third objective was to compare the empirically determined clusters with the classification into the CEE countries and the advanced EU countries, and see whether the CEE and Western countries would be bundled in separated clusters, or whether they would form some mixed groups that would signify a trend toward convergence.

Our analyses draw upon the recent evidence from the database of the Fifth European Working Condition Survey (EWCS).The fieldwork was carried out from January till June 2010 in 34 European countries (27 EU Member States, Croatia, Norway, the Former Yugoslav Republic of Macedonia, Turkey, Albania, Montenegro and Kosovo). ${ }^{2}$ Multi-stage, stratified, random samples were used. The countries were divided into sections based on region and the degree of urbanization; in each section, a number of primary sampling units were drawn randomly, and then a random sample of households was selected from each unit. Finally, in each household, the person in employment with the closest coming birthday was chosen for the interview. The target sample size in most countries was 1,000 , with the exception of some countries that financed larger national samples to be used for policy planning (1,400 in Slovenia; 1,500 in Italy, Poland, and UK; 2,000 in Germany and Turkey; 3,000 in France; and 4,000 in Belgium). The total number of participants was close to 44,000 , but in the present 
DRUŠ. ISTRAŽ. ZAGREB GOD. 23 (2014), BR. 4 STR. 557-575

ŠVERKO, B., GALIĆ, Z.: THE PERCEIVED... analyses we used only the data from the EU member states $(\mathrm{N}=36,472)$.

The interviews conducted in the participants' homes were based on a carefully prepared and pre-tested questionnaire. The master questionnaire form in English was translated into other languages in a four-step procedure: (1) two independent experts translated the questionnaire into their language, (2) a third person combined these versions into one, (3) this version was then translated back into English, and (4) a final version was validated by national experts on working conditions research.

\section{Developing QWL measures: selection of items for the four dimensions}

Drawing on the same database, Green and Mostafa (2012) already constructed four job quality indices, and generously offered the programs for computing the indices. However, their indices were not sufficiently compatible with our conceptualization of the QWL dimensions. Besides, some of their indices aggregate mutually unrelated lower-level indicators. For example, the "Intrinsic job quality" index aggregates the following sub-indices: "Skills and discretion", "Good social environment", "Good physical conditions", and "Work intensity". Since they are all important, and yet largely unrelated, aggregating them into one composite measure is theoretically and methodologically dubious. Hence, we decided to develop our own set of the EWCS based measures of the quality of working life.

The EWCS questionnaire covered various aspects of working conditions, but the content varied strongly across the aspects, and the items employed a variety of formats, ranging from the Likert-type items to simple yes/no questions. By and large, authors of comparative studies try to make use of all available items. As a consequence, the resulting "indices" are often nontransparent and conceptually dubious. In this study, we opted for a smaller number of homogeneous items that are (1) most pertinent to the four QWL dimensions defined in the introductory section, and (2) share a similar and metrically better response format. By careful examination of all questionnaire items, we sorted out 16 Likert-type items presented in Table 1. Each item is simply a statement for which respondents are asked to evaluate themselves on a five-point importance or likelihood response continuum (shown in the table's footnote). The items within each QWL category are seen as the correlated indicators of the underlying QWL dimensions, which are themselves conceived as relatively independent variables. 
1. Economic security

Q77B I am well paid for the work I do

Q77A I might lose my job in the next 6 months

Q77C My job offers good prospects for career advancement

${ }^{*}$ Q77F If I were to lose or quit my current job, it would be easy for me to find a job of similar salary

2. Social relationship at work

Q77E I have very good friends at work

Q51B Your manager helps and supports you

Q51A Your colleagues help and support you

*Q77D I feel 'at home' in this organisation

3. Meaningfulness of work

Q51H Your job gives you the feeling of work well done

${ }^{*}$ Q51I You are able to apply your own ideas in your work

Q51J You have the feeling of doing useful work

4. Autonomy and participation in making decisions

Q51F You can take a break when you wish

Q51D You are involved in improving the work organisation or work processes of your department or organisation

Q51E You have a say in the choice of your working partners

Q510 You can influence decisions that are important for your work

Q51C You are consulted before targets for your work are set

\section{(1) TABLE 1}

Statements chosen for

the quality of working

life scales
Notes:

1. A code preceding each statement denotes its position number in the EWCS questionnaire.

2. The response scale for Q77 statements was: Strongly agree (5), Agree (4), Neither agree nor disagree (3), Disagree (2), Strongly disagree (1); and for Q51 statements: Always (1), Most of the time (2), Sometimes (3), Rarely (4), Never (5).

3. The statement Q77A and all Q51 statements were recoded prior to the analyses.

4. Statements denoted with an asterisk were discarded after the factor analyses.

\section{Evaluation of the QWL measures: \\ Factor analysis and external correlates}

The 16 items were first subjected to an exploratory factor analysis. The principal axis factoring method was used. Both the Kaiser-Guttmann criterion and the Scree-plot supported our assumption about four latent dimensions of the QWL. In total, the four factors explained $40.2 \%$ variance of the 16 items. The factors were obliquely rotated using the oblimin rotation.

Thirteen out of the 16 items had the highest loadings on 
DRUŠ. ISTRAŽ. ZAGREB GOD. 23 (2014), BR. 4 STR. 557-575

ŠVERKO, B., GALIĆ, Z.: THE PERCEIVED..
Table 1) "failed" the exploratory factor analysis: two had the highest loadings with the factor other than the one they were supposed to measure (item Q77D with the Economic security, and item Q51I with the Autonomy/participation), whereas the factor saturation for the item Q77F was too low (0.16 with the Economic security factor).

The 13 items that "passed" the exploratory factor analysis were then subjected to a confirmatory factor analysis. The results showed an acceptable model fit of the four factors to the 13 items with independent error terms (GFI $=0.96$, RMSEA $=0.065 ; 90 \%$, RMSEA CI $[0.065,0.067]) .^{3}$ The four latent factors were positively albeit weakly correlated: the correlations ranged between 0.10 and 0.29 , which was in accordance with our theoretical position about the four distinct categories of psychological needs that together define the overall QWL. All correlations were significant at $p<0.001$ level, mostly due to the large size of the sample.

In all further analyses we used the so-called real factor scores, i.e. averaged ratings of the items measuring each of the factors. Their intercorrelations ranged between 0.27 (Economic security and Social relations) and 0.36 (Social relations and Autonomy/participation) and were all significant at $p<0.001$ level. The reliability values of three of the four scales were above the level that is considered satisfactory for research purposes (0.60; Carmines \& Zeller, 1979). Cronbach alphas for Social relations, Job meaningfulness, and Autono$\mathrm{my} /$ participation scales were $0.65,0.75$ and 0.77 , respectively. For the Economic security scale the alpha coefficient was suboptimal (0.50); this barely acceptable value is probably the result of the heterogeneity in the content of the items.

In order to further support the construct validity of the QWL scales, we explored their correlations with the theoretically related variables. Since the quality of working life is generally conceived as a predictor of well-being at work, we looked for the well-being indices in the EWCS questionnaire. We found three relevant measures: subjective health (assessed by Q68 and Q69); psychological well-being (assessed by a five-item scale EF4) and job satisfaction (Q76). ${ }^{4}$ The correlation between the four QWL scales and the three well-being measures were all significant and in the expected direction. The multiple correlations for the four QWL dimensions explaining the criterion variables were as follows: 0.34 for subjective health, 0.39 for psychological well-being, and 0.55 for job satisfaction. This is a theoretically sound finding: the percentages of individual differences in subjective health, psychological well-being and job satisfaction explained by our QWL indices were reasonably high $(34,39$, and $55 \%$, respectively), and the QWL level primarily reflected in immediate 
job satisfaction, and less in subjective health, which represents its more distant consequence. Thus, the obtained pattern of correlations supported the construct validity of our QWL scales.

\section{RESULTS}

(1) TABLE 2

Comparison of the quality of working life (QWL) mean scores of the Croatian (HR), the Western European (EU17) and the

Central and Eastern European (EU10) participants
We first compared the mean scores of the Croatian participants with the mean scores of the two sets of the EU countries (EU17 and EU10). As we have already explained, the EU17 group comprised 17 established market economies of Western Europe, including the two Mediterranean island countries, and the second set (EU10) ten transitional CEE countries. The samples comprised 36,472 participants $(24,424$ in EU17, 10,948 in EU10, and 1,100 in the Croatian sample). However, the actual sample sizes differed among the analyses. The reason was the systematic dropout of the participants due to the content of some of the questionnaire items. For example, participants who were self-employed or worked in companies as the only employee could not rate their peers or manager(s). The fact that certain aspects of the QWL scale were not applicable to all jobs was the main cause of the differences in the sample sizes among the analyses.

The multivariate analysis of variance (MANOVA) has shown that the three compared groups (EU17, Croatia, and EU10) differed significantly in the quality of working life (Pillai Trace $\mathrm{F}=218.15 ; \mathrm{df}=8 / 47,098 ; \mathrm{p}<0.001$ ). The mean scores (and standard deviations) on the four QWL dimensions for the three groups of participants and univariate ANOVAs are given in Table 2.

\begin{tabular}{|c|c|c|c|c|c|c|}
\hline \multirow[b]{2}{*}{ QWL dimensions } & \multicolumn{3}{|c|}{$\begin{array}{l}\text { Means } \\
\text { (Standard deviations) }\end{array}$} & \multicolumn{3}{|l|}{ ANOVA } \\
\hline & EU17 & $\mathrm{HR}$ & EU10 & $\mathrm{F}$ & $\mathrm{df}$ & $\begin{array}{l}\text { Post hoc analysis } \\
\text { (Tukey HSD test) }\end{array}$ \\
\hline Economic security ${ }^{a}$ & $\begin{array}{l}3.29 \\
(0.81)\end{array}$ & $\begin{array}{l}2.98 \\
(0.85)\end{array}$ & $\begin{array}{l}2.87 \\
(0.83)\end{array}$ & $886.97^{* * *}$ & 2,31980 & $\begin{array}{l}\mathrm{EU} 17>\mathrm{HR}^{* * *} \\
\mathrm{EU} 17>\mathrm{EU} 10^{* * *} \\
\mathrm{HR}>\mathrm{EU} 10^{* * *}\end{array}$ \\
\hline Social relations ${ }^{a}$ & $\begin{array}{l}3.88 \\
(0.81)\end{array}$ & $\begin{array}{l}4.05 \\
(0.71)\end{array}$ & $\begin{array}{l}3.86 \\
(0.78)\end{array}$ & $20.51^{* * *}$ & 2,27749 & $\begin{array}{l}\mathrm{HR}>\mathrm{EU} 17^{* * *} \\
\mathrm{HR}>\mathrm{EU} 10^{* * *}\end{array}$ \\
\hline $\begin{array}{l}\text { Meaningfulness } \\
\text { of work }{ }^{\mathrm{a}}\end{array}$ & $\begin{array}{l}4.31 \\
(0.78)\end{array}$ & $\begin{array}{l}4.22 \\
(0.79)\end{array}$ & $\begin{array}{l}4.26 \\
(0.80)\end{array}$ & $19.23^{* * *}$ & 2,35925 & $\begin{array}{l}\mathrm{EU} 17>\mathrm{HR}^{* * *} \\
\mathrm{EU} 17>\mathrm{EU} 10^{* * *}\end{array}$ \\
\hline $\begin{array}{l}\text { Autonomy and } \\
\text { participation }^{\mathrm{a}}\end{array}$ & $\begin{array}{l}2.94 \\
(1.04)\end{array}$ & $\begin{array}{l}2.89 \\
(1.01)\end{array}$ & $\begin{array}{l}2.91 \\
(1.04)\end{array}$ & $4.92^{* *}$ & 2,28997 & EU17 > EU10* \\
\hline
\end{tabular}

Note. aresponses are given on a five-point scale where 1 reflects the lowest and 5 the highest perceived QWL; ${ }^{* *} \mathrm{p}<0.001 ;{ }^{* *} \mathrm{p}<0.01 ;{ }^{*} \mathrm{p}<0.05$. 
DRUŠ. ISTRAŽ. ZAGREB GOD. 23 (2014), BR. 4 STR. 557-575

ŠVERKO, B., GALIĆ, Z. THE PERCEIVED..
In order to understand the differences among the groups of countries better, we performed univariate analyses of variance (ANOVA) with Tukey's HSD post-hoc comparisons for each of the QWL dimensions. The results are given in the last column of Table 2. As can be seen, the ANOVAs revealed significant differences among the three groups of participants for each of the four components of QWL. A closer inspection of the means and post-hoc test results for each of the QWL dimensions reveals the following:

- The EU17 participants rated their economic security substantially higher than the EU10 participants. The Croatian mean was intermediate. The post hoc analysis revealed that all differences between the pairs of groups were significant at $\mathrm{p}<0.001$ level.

- The Croatian participants rated their social relations at work more favorably than those in the other two groups $(p<0.001)$. The EU17 and the EU10 participants did not differ between each other $(p>0.05)$.

- The EU17 participants rated the meaningfulness of their work more favorably than the other two groups $(p=0.011)$, which did not differ between each other ( $p>0.05)$.

- The EU17 participants rated the autonomy in work and participation in making decisions more favorable than the EU10 participants $(p<0.05)$. Other differences among the groups were not significant $(p>0.05)$.

Thus, according to the comparison of the mean scores, the EU17 countries outperform the EU10 countries in three out of the four QWL dimensions, particularly in economic security.

Our next analysis explored the sub-divisions of the countries. In order to see how the EU countries group in QWL (and where Croatia fits in), we performed a hierarchical cluster analysis using the countries' means on the thirteen QWL items as the clustering variables. The analysis was performed on the standardized variables, so they contribute equally to the similarity between the countries (Nourosis, 2003). We used the Euclidian distances as a measure of the distance between the cases, and Ward's method as the procedure of the cluster creation. Based on our interpretability considerations and the parsimony principle, a five-cluster solution was chosen. The members of the clusters and the tentative labels are listed in the first column of Table 3 .

As the mean values and the ANOVA results reveal, Continental, Nordic, and Expanded Anglophone clusters appreciably exceed the other two clusters in Economic security. A significant difference among the clusters was also observed in Social relations, with the Expanded Anglophone countries scoring highest, and the Continental and Transition 2 coun- 
() TABLE 3

Quality of working life components in the five clusters: descriptive statistics and ANOVA results tries lowest. In the Meaningfulness of work, one cluster was significantly different from all other clusters: the Transition 2 cluster scored below all of the other four. In Autonomy/participation, the Nordic cluster significantly outscored the other four clusters.

\begin{tabular}{|c|c|c|c|c|}
\hline \multirow[b]{2}{*}{ Clusters of countries } & \multicolumn{4}{|c|}{ QWL dimensions } \\
\hline & $\begin{array}{l}\text { Economic } \\
\text { security }^{a}\end{array}$ & $\begin{array}{l}\text { Social } \\
\text { relations }\end{array}$ & $\begin{array}{l}\text { Meaningful- } \\
\text { ness of work }\end{array}$ & $\begin{array}{l}\text { Autonomy/ } \\
\text { participation }^{\mathrm{a}}\end{array}$ \\
\hline $\begin{array}{l}\text { Cluster 1: CONTINENTAL } \\
\text { Austria, Belgium, France, Germany, Italy, } \\
\text { Luxemburg, Poland }\end{array}$ & $3.28(0.17)$ & $3.64(0.13)$ & $4.29(0.05)$ & $2.91(0.08)$ \\
\hline $\begin{array}{l}\text { Cluster 2: NORDIC } \\
\text { Denmark, Finland, Sweden, Netherlands }\end{array}$ & $3.36(0.20)$ & $3.93(0.18)$ & $4.31(0.15)$ & $3.38(0.05)$ \\
\hline $\begin{array}{l}\text { Cluster 3: EXPANDED ANGLOPHONE } \\
\text { Cyprus, Ireland, Malta, UK }\end{array}$ & $3.35(0.09)$ & $4.21(0.10)$ & $4.38(0.26)$ & $3.12(0.06)$ \\
\hline $\begin{array}{l}\text { Cluster 4: TRANSITIONAL \& SOUTHERN } \\
\text { Bulgaria, Croatia, Estonia, Greece, Hungary, } \\
\text { Latvia, Portugal, Romania, Slovenia, Spain }\end{array}$ & $2.89(0.14)$ & $3.96(0.06)$ & $4.35(0.10)$ & $3.02(0.17)$ \\
\hline $\begin{array}{l}\text { Cluster 5: TRANSITIONAL } 2 \\
\text { Czech Republic, Lithuania, Slovakia }\end{array}$ & $2.84(0.18)$ & $3.71(0.04)$ & $4.00(0.09)$ & $2.86(0.15)$ \\
\hline ANOVA F $(4,23)$ & $14.50^{* * *}$ & $21.67^{* * *}$ & $4.52^{* *}$ & $11.01^{* * *}$ \\
\hline $\begin{array}{l}\text { Pairs of clusters that significantly differed } \\
\text { using the Tukey HSD post hoc comparison } \\
\text { (first member in the pair had a significantly } \\
\text { higher score) }\end{array}$ & $\begin{array}{l}1-4^{* * *} ; 1-5^{* *} \\
2-4^{* * *} ; 2-5^{* *} \\
3-4^{* * *} ; 3-5^{* *}\end{array}$ & $\begin{array}{l}2-1^{* *} ; \\
3-1^{* * *} ; 3-2^{*} \\
3-4^{* *} ; 3-5^{* * *} \\
4-1^{* * *} ; 4-5^{*}\end{array}$ & $\begin{array}{l}1-5^{*} \\
2-5^{*} ; \\
3-5^{* *} \\
4-5^{* *}\end{array}$ & $\begin{array}{l}2-1^{* * * *} \\
2-4^{* *} \\
2-5^{* * *}\end{array}$ \\
\hline
\end{tabular}

Note. aresponses are given on a five-point scale where 1 reflects the lowest and 5 the highest perceived QWL; ${ }^{* * *} \mathrm{p}<0.001 ;{ }^{* *} \mathrm{p}<0.01 ;{ }^{*} \mathrm{p}<0.05$.

\section{DISCUSSION}

Croatia's recent accession to the EU inspired our initial research question: how the quality of working life in Croatia compares to that in the joined community. As the EU expands its borders, the differences in QWL between various countries will motivate an increasing number of skilled workers to seek employment anywhere in the EU. Knowing the levels of QWL in various countries may help policy planners to predict the flow of labor migration better. On a broader level, since the quality of working life is a component of overall well-being, the QWL comparison may serve as a benchmark in the evaluation of the transition process. All too often the evaluation of the transition progress relies on political and economic criteria (such as the degree of democratization and privatization, or the implementation of economic reforms), reflecting more the means than the ends. However, we are also eager to learn whether and how ordinary people benefit from the transition in the quality of their (working) life. 
DRUŠ. ISTRAŽ. ZAGREB GOD. 23 (2014), BR. 4 STR. 557-575

ŠVERKO, B., GALIĆ, Z.: THE PERCEIVED...
Our results indicate that the transition has not been very beneficial so far: the CEE countries significantly lag behind the Western ones. They score lower on three out of the four QWL dimensions. Accordingly, the cluster analysis has revealed that the countries of Eastern and Western Europe split into different groups. Almost all Western European countries assort into three clusters, which we have termed Nordic, Continental, and Expanded Anglophone. On the other hand, the transitional CEE countries are bundled together in two additional clusters. There are only a few exceptions: Poland, a transitional country, has joined the Continental cluster, while Greece, Portugal, and Spain have joined the group of CEE countries in Cluster 4 . These exceptions, which can be traced to the economic circumstances in the recent years (a steady economic growth in Poland and continuous economic difficulties in the southern EU states - Eurostat, 2014), do not change the general impression of the divergence between the transitional and the advanced Western countries. The divergence was further supported when we compared the clusters in job satisfaction in an additional analysis. The results on the one-item job satisfaction measure from the EWCS (Q76) revealed significantly higher job satisfaction in the three Western European clusters in comparison to the Transitional \& Southern and Transitional 2 clusters. Both groups of clusters did not differ significantly within themselves. Thus, almost a quarter of a century since the transition began, our results point to a clear "QWL divide" in the European Union.

The main QWL difference among the three advanced clusters of countries and the two transitional clusters is in the economic security dimension. This QWL dimension (i.e., security of employment and pay) was recently shown to be the key work life determinant of "general" life satisfaction (Drobnič, Benaham, \& Präg, 2010). In order to assess its relation to the degree of economic development, we correlated the GDP per capita for all 28 countries obtained from the Eurostat database with their scores on the four QWL dimensions. There was a weak tendency of the GDP to be positively correlated with the autonomy / participation $(\mathrm{r}=0.22)$ and the meaningfulness of work (0.06), and negatively with the social relations $(-0.10)$ scales, but these correlations were not statistically significant. The only substantial correlation is between the GDP and the economic security score $(0.73 ; \mathrm{p}<0.05)$, showing that the richer countries offered better economic security aspects of the QWL. Although we may speculate which comes first, wealth or welfare, it is certain that the wealthier countries can invest more in QWL and provide better economic security. This, in turn, affects satisfaction and productivity of the existing work force, but it also attracts migrants from 
DRUŠ. ISTRAŽ. ZAGREB GOD. 23 (2014), BR. 4, STR. 557-575

ŠVERKO, B., GALIĆ, Z.: THE PERCEIVED... poorer countries. Since migrants tend to be enterprising and skilled individuals, their destination countries generally gain from their migration. Their home counties, however, in spite of the short-term benefits, in the long run are at a loss because they lose gifted people. Ultimately, this process may deepen the existing differences.

Although this was not the focus of our research, it is interesting to note that the clusters identified in our study bear resemblance to the welfare regime models initially suggested by Esping-Andersen (1990). Based on the notion of "decommodification" (roughly, the degree to which welfare services are free from the influence of the market) and the kind of social stratification fostered by social policies, the typology originally postulated three basic welfare models: the liberal (or market-oriented) welfare states characteristic of the Anglo-American democracies, the conservative regime predominant in continental Europe, and the Nordic social democratic policy model. Some authors (e.g., Bonoli, 1997; Ferrera 1996) later added the Mediterranean type as another model of the welfare state, and more recent analyses sought to extend the typology to include the transitional, post-socialist family of nations (Castles \& Obinger, 2008; Fenger, 2007). These welfare regimes represent different ways of organizing a society, not only the welfare policy, but also the productive sector of the capitalistic economy (Goodin, Headey, Muffels, \& Driven, 1999). Esping-Andersen (1999) considers the welfare regimes not only as an outcome of the societal organization, but also as the antecedent structures capable of explaining various dependent variables, including social behavior and attitudes.

The three clusters that emerged in our analysis (Nordic, Continental, and Expanded Anglophone), in their composition and in some of the characteristics, fairly correspond to Esping-Andersen's social-democratic, conservative, and liberal institutional models. The Southern and CEE countries formed the remaining two clusters. While empirical studies of the welfare typologies typically relied on macro indicators, our cluster analysis was based on the perception of the quality of work life. Yet the clustering roughly reproduced the postulated typology of welfare states. This finding is consistent with the work by Gallie (2007a, 2007b, 2009), who provided evidence that the variations in European institutional regimes were related to the cross-national variation in certain aspects of job quality. More recently, Holman (2013) confirmed that European countries with various institutional regimes (e.g., social-democratic, continental, liberal, southern European, transitional) exhibit differences in both the level and the nature of job quality. 
DRUŠ. ISTRAŽ. ZAGREB GOD. 23 (2014), BR. 4 STR. 557-575

ŠVERKO, B., GALIĆ, Z.: THE PERCEIVED...

\section{Limitations}

We now turn to the Croatian results. According to the general pattern of the QWL scores, Croatia ended up in the Transitional \& Southern cluster, together with Bulgaria, Estonia, Greece, Hungary, Latvia, Portugal, Romania, Slovenia and Spain. While the Croatian ratings of the economic security are commeasured to the country's GDP, the ratings of the meaningfulness of work and the autonomy and participation are relatively low. However, Croatia's forte are high ratings of human relations at work. As can be seen in Table 2, Croatia's mean score for social relations was higher than the mean scores of either the EU10 or the EU17 countries. This finding corroborates our earlier observations. In a series of studies which examined job-aspect perceptions over time (Maslić Seršić \& Šverko, 2000; Maslić Seršić, Šverko, \& Galić, 2005; Šverko \& Galić, 2009; Galić \& Plećaš, 2012), it was repeatedly found that the relationship with one's coworkers was the best rated job aspect. This has now been confirmed in an international comparison. It is not easy to explain this finding. The international findings of the Work Importance Study (Super \& Šverko, 1995) indicated that Croatian participants valued altruism and human relations more than the other national groups did. It is possible that such value pattern translates into behavior that facilitates getting along with other people at work. Whatever the reasons, it seems that Croatian workers still enjoy non-competitive, perhaps even co-operative, work environments that improve the quality of their working life.

Two limitations of this study should be noted. The first limitation concerns the exhaustibility of the QWL measures. Based on the psychological needs theories, this paper focuses on economic security, social relations at work, work meaningfulness, and autonomy/participation in making decisions as the core dimensions of the quality of working life. There are, however, other job attributes that may be important too. One is the speed and pressures under which work is carried out. Variously conceived as "work effort" (Green, 2006), "hard, stressful or dangerous job" (Clark, 2005) or "work intensity" (Gallie, 2013), this factor has often been taken as an attribute of job quality. Although one might argue that in our conceptual model work intensity could join other economic security indicators to form a more encompassing QWL category related to the basic psychological needs (Maslow, 1954), the main reasons we omitted it from the model were methodological: the available questionnaire items did not promise a clear-cut operationalization of work intensity, which probably bears a curvilinear relation to job quality. 5 The second limitation con- 
DRUŠ. ISTRAŽ. ZAGREB GOD. 23 (2014), BR. 4, STR. 557-575

ŠVERKO, B., GALIĆ, Z.: THE PERCEIVED.. cerns the sufficiency of the items tapping the four dimensions. As already noted, we used questionnaire items that were (1) most pertinent to the four QWL dimensions, and (2) shared similar Likert-type format. Not many such items were found in the EWCS questionnaire. As a consequence, the internal consistency coefficients are somewhat reduced (especially for the economic security scale). These two limitations are often encountered when one attempts to operationalize a theoretical construct within eclectic questionnaires from the large-scale surveys intended to serve various purposes. Despite these limitations, the findings of this study appear to be a compelling contribution to the understanding of the differences in the perceived quality of working life across Europe.

\section{NOTES}

\section{REFERENCES}

${ }^{1}$ Croatia joined the EU as its 28th member state on July 1st 2013.

2 The fieldwork was carried out by a network of national institutes, coordinated by Gallup Europe. They worked within a strong quality assurance framework to ensure high standards in obtaining and editing of all the data. For more information see the Technical Report (http://www.eurofound.europa.eu/surveys/ewcs/2010/documents/ technical.pdf).

${ }^{3}$ In accordance with a reviewer's suggestion, we tried to fit the measurement model where the item Q51I was the indicator of the Autonomy/participation factor. Considering that the inclusion led to significantly worse model fit indices, we decided to omit the item from further analyses.

4 The items tapping well-being and satisfaction may be found in the master questionnaire at http://www.eurofound.europa.eu/surveys/ ewcs/2010/

5 These difficulties have already been noted by Green and Mostafa (2012), who attempted to construct a summative work intensity index drawing on the same database.

Alderfer, C. P. (1972). Existence, relatedness, and growth: Human needs in organizational settings. New York: Free Press

Bonoli, G. (1997). Classifying welfare states: A two-dimension approach. Journal of Social Policy, 26(3), 351-372. doi:10.1017/S0047279497005059

Carmines, E. G., \& Zeller, R. A. (Eds.) (1979). Reliability and validity assessment (Vol. 17). Beverly Hills, CA: Sage. doi:10.4135/9781412985642

Castles, F. G., \& Obinger, H. (2008). Worlds, families, regimes: Country clusters in European and OECD area public policy. West European Politics, 31(1-2), 321-344. doi:10.1080/01402380701835140

Clark, A. E. (2005). What makes a good job? Evidence from OECD countries. In S. Bazen, C. Lucifora, \& W. Salverda (Eds.), Job quality and employer behavior (pp. 11-30). Basingstoke: Palgrave Macmillan. 
DRUŠ. ISTRAŽ. ZAGREB GOD. 23 (2014), BR. 4 STR. 557-575

ŠVERKO, B., GALIĆ, Z. THE PERCEIVED..
Davis, L. E. (1977). Enhancing the quality of working life: Development in the United States. International Labour Review, 116(1), 53-65.

Davis, L. E., \& Cherns, A. B. (Eds.) (1975). The quality of working life (Vols. 1 and 2). New York: Free Press.

Deci, E. L., \& Ryan, R. M. (1985). Intrinsic motivation and self-determination in human behavior. New York: Plenum. doi:10.1007/978-1-48992271-7

Deci, E. L., \& Ryan, R. M. (2000). The "what" and "why" of goal pursuits: Human needs and the self-determination of behavior. Psychological Inquiry, 11(4), 227-268. doi:10.1207/S15327965PLI1104_01

Drobnič, S., Beham, B., \& Präg, P. (2010). Good job, good life? Working conditions and quality of life in Europe. Social Indicators Research, 99(2), 205-225. doi:10.1007/s11205-010-9586-7

Efraty, D., \& Sirgy, M. J. (1990). The effects of quality of working life (QWL) on employee behavioral responses. Social Indicators Research, 22(1), 31-47. doi:10.1007/BF00286389

Elizur, D., \& Shye, S. (1990). Quality of work life and its relation to quality of life. Applied Psychology: An International Review, 39(3), 275-291.

Esping-Andersen, G. (1990). The three worlds of welfare capitalism. Princeton: Princeton University Press.

Esping-Andersen, G. (1999). Social foundations of post-industrial economies. Oxford: Oxford University Press. doi:10.1093/0198742002.001.0001

Eurofound (2007). Fourth European Working Conditions Survey. Luxembourg: Office for Official Publications of the European Communities. Eurostat (2014). Real GDP growth rate. Available at http://epp.eurostat. ec.europa.eu/portal/page/portal/eurostat/home/

Fenger, H. J. M. (2007). Welfare regimes in Central and Eastern Europe: Incorporating post-communist countries in a welfare regime typology. Contemporary Issues and Ideas in Social Sciences, 3(2), 1-30. Available at http://hdl.handle.net/1765/34876

Ferrera, M. (1996). The southern model of welfare in social Europe. Journal of European Social Policy, 6(1), 17-37. doi:10.1177/0958928796 00600102

Findlay, P., Kalleberg, A. L., \& Warhurst, C. (2013). The challenge of job quality. Human Relations, 66(4), 441-451. doi:10.1177/0018726713481070

Galić, Z., \& Plećaš, M. (2012). Quality of working life during the recession: The case of Croatia. Croatian Economic Survey, 14(1), 5-41.

Gallie, D. (2007a). Production regimes and the quality of employment in Europe. Annual Review of Sociology, 33, 85-104. doi:10.1146/ annurev.soc.33.040406.131724

Gallie, D. (Ed.) (2007b). Employment regimes and the quality of work. Oxford: Oxford University Press. doi:10.1093/acprof:oso/978019923 0105.001.0001

Gallie, D. (2009). Institutional regimes and employee influence at work: A European comparison. Cambridge Journal of Regions, Economy and Society, 2(3), 379-393. doi:10.1093/cjres/rsp010

Gallie, D. (Ed.) (2013). Economic crisis, quality of work, and social integration: The European experience. Oxford: University Press. doi:10.1093/ acprof:oso/9780199664719.001.0001 
DRUŠ. ISTRAŽ. ZAGREB GOD. 23 (2014), BR. 4, STR. 557-575

ŠVERKO, B., GALIĆ, Z.: THE PERCEIVED...
Goodin, R. E., Headey, B., Muffels, R., \& Dirven, H.-J. (1999). The real worlds of welfare capitalism. Cambridge University Press: Melbourne. doi:10.1017/CBO9780511490927

Green, F. (2006). Demanding work. The paradox of job quality in the affluent economy. Princeton, NJ and Oxford: Princeton University Press.

Green, F., \& Mostafa, T. (2012). Trends in job quality in Europe. European Union.

Guest, R. H. (1979). Quality of work life-learning from Tarrytown. Harvard Business Review, July-August, 28-39.

Hackman, J. R., \& Oldham, G. R. (1976). Motivation through the design of work: Test of a theory. Organizational Behavior and Human Performance, 16(2), 250-279. doi:10.1016/0030-5073(76)90016-7

Harter, J. K., Schmidt, F. L., Asplund, J. W., Killham, E. A., \& Agrawal, S. (2010). Causal impact of employee work perceptions on the bottom line of organizations. Perspectives on Psychological Science, 5(4), 378-389. doi:10.1177/1745691610374589

Herzberg, F. (1966). Work and the nature of man. New York: World Publishing Company.

Herzberg, F., Mausner, B., \& Snyderman, B. B. (1959). The motivation to work. New York: John Wiley \& Sons.

Holman, D. (2013). Job types and job quality in Europe. Human Relations, 66(4), 475-502. doi:10.1177/0018726712456407

Kornbluh, H. (1984). Work place democracy and quality of work life: Problems and prospects. Annals of the American Academy of Political and Social Science, 473(1), 88-95. doi:10.1177/0002716284473001009

Lawler, E. E. (1975). Measuring the psychological quality of working life: The why and how of it. In L. E. Davis, \& A. B. Cherns (Eds.), The quality of working life (Vol. 1, pp. 123-133). New York: Free Press.

Lawler, E. E. (1982). Strategies for improving the quality of work life. American Psychologist, 37(5), 486-493. doi:10.1037/0003-066X.37.5.486

Martel, J.-P., \& Dupuis, G. (2006). Quality of work life: Theoretical and methodological problems, and presentation of a new model and measuring instrument. Social Indicators Research, 77(2), 333-368. doi:10.1007/s11205-004-5368-4

Maslić Seršić, D. \& Šverko, B. (2000). Croatian workers in the period of transition: A five-year follow-up of job-related attitudes. Social Science Information, 39(2), 363-376. doi:10.1177/053901800039002012

Maslić Seršić, D., Šverko, B., \& Galić, Z. (2005). Radne vrijednosti i stavovi prema poslu u Hrvatskoj: što se promijenilo $u$ odnosu na devedesete? (Work values and job-related attitudes in Croatia: What changed in comparison with the 1990s?). Društvena istraživanja, 14(6), 1039-1054.

Maslow, A. H. (1954). Motivation and personality. New York: Haper McClelland, D. C. (1985). Human motivation. NY: Cambridge University Press.

Norusis, M. (2003). SPSS for windows, version 11.5. Chicago, IL: SPSS. 
DRUŠ. ISTRAŽ. ZAGREB GOD. 23 (2014), BR. 4 STR. $557-575$

ŠVERKO, B., GALIĆ, Z.: THE PERCEIVED...
Sirgy, M. J., Efraty, D., Siegel, P. \& Lee, D.-J. (2001). A new measure of quality of work life (QWL) based on need satisfaction and spillover theories. Social Indicators Research, 55(3), 241-302. doi:10.1023/A:1010 986923468

Super, D. E., \& Šverko, B. (Eds.) (1995). Life roles, values, and career: International findings of the Work Importance Study. San Francisco: Jossey Bass Publishers.

Šverko, B., \& Galić, Z. (2009). Kvaliteta radnog života u Hrvatskoj: subjektivne procjene tijekom posljednjih 15 godina (Quality of working life in Croatia: Subjective ratings during the last 15 years). In V. Franičević, \& V. Puljiz (Eds.), Rad u Hrvatskoj: pred izazovima budućnosti (Labour in Croatia: Facing challenges of future), (pp. 197-223). Zagreb: Centar za demokraciju i pravo Miko Tripalo and Pravni fakultet Sveučilišta u Zagrebu.

Warr, P. (1999). Well-being and the workplace. In D. Kahneman, E. Diener, \& N. Schwarz (Eds.), Well-being: The foundations of hedonic psychology (pp. 392-412). New York, U.S.: Russell Sage Foundation.

Warr, P. (2007). Work, happiness, and unhappiness. New Jersey: Lawrence Erlbaum Associates, Inc., Publishers.

\section{Percipirana kvaliteta radnoga života $u$ Hrvatskoj i Europskoj uniji}

Branimir ŠVERKO, Zvonimir GALIĆ

Filozofski fakultet, Zagreb

U ovoj studiji istraživali smo percipiranu kvalitetu radnoga života u Hrvatskoj i dvije skupine preostalih EU članica: EU 17, skupine razvijenih tržišnih ekonomija Zapadne Europe, i EU 10, skupine zemalja iz Srednje i Istočne Europe. Analiza se temelii na podacima Pete europske ankete o radnim uvjetima, koja je provedena 2010. godine. Broj sudionika bio je 24.424 u EU 17, 10.948 u EU 10 te 1100 u hrvatskom uzorku. Naša mjera kvalitete radnoga života sadržavala je sljedeće četiri dimenzije: (1) ekonomsku sigurnost, (2) socijalne odnose na poslu, (3) smislenost posla, (4) autonomiju i sudjelovanje u donošenju odluka. Rezultati su pokazali da zemlje Srednje i Istočne Europe zaostaju za zapadnoeuropskim EU članicama, posebice u ekonomskoj sigurnosti. U hijerarhijskoj klasterskoj analizi dvije skupine zemalja grupirale su se u odvojene klastere, upozoravajući na to da podjela na europski Istok i Zapad u kvaliteti radnoga života postoji i danas. Hrvatska se, unatoč visokim procjenama kvalitete socijalnih odnosa na poslu, grupirala s ostalim tranzicijskim zemljama.

Ključne riječi: kvaliteta radnoga života, kvaliteta posla, međunarodna usporedba, Europska unija, Hrvatska 